\title{
Entre flores e canhões na Grande Guerra (1914-1918): o final da Belle Époque e o começo do "breve século XX" em um álbum de retratos fotográficos
}

Between flowers and cannons in the Great World War (1914-1918): the end of Belle Époque and the beginning of the "Brief $20^{\text {th }}$ Century" in an album of portraits

Marco Antonio Stancik *

Resumo

O trabalho analisa oito retratos fotográficos pertencentes a um álbum de família alemão, sete dos quais datados dos tempos da Primeira Guerra Mundial (19141918). As fotografias são abordadas como documentos e monumentos, de forma a evidenciar mudanças operadas na percepção do conflito, a partir de uma narrativa construída sob sua inspiração. Palavras-chave: fotografia; Primeira Guerra Mundial; fontes historiográficas.

\section{Abstract}

The paper explores eight portraits of a German family album. Seven portraits dated the times of Great World War (1914-1918). The portraits are addressed as documents and monuments to reveal changes in the perception of conflict through the writing of a narrative related to selected photographs. Keywords: photography; First World War; historical sources.

Ora, a partir do momento que me sinto olhado pela objetiva, tudo muda: ponho-me a "posar", fabrico-me instantaneamente um outro corpo, metamorfoseio-me antecipadamente em imagem. ... uma imagem - minha imagem - vai nascer: vão me fazer nascer um indivíduo antipático ou um "sujeito distinto"?

Roland Barthes ${ }^{1}$

\footnotetext{
* Doutor em História pela UFPR. Instituto Agronômico do Paraná (Iapar) - Polo Regional de Ponta Grossa. Rod. Presidente Kennedy, km 496. 84043-540 Ponta Grossa - PR - Brasil. marcostancik@hotmail.com
} 
As fotos dão às pessoas a posse imaginária de um passado irreal ... A força de uma foto reside em que ela mantém abertos para escrutínio instantes que ofluxo normal do tempo substitui imediatamente.

Susan Sontag ${ }^{2}$

Em 11 de novembro de 1918, foi assinado o armistício que encerrou a Primeira Guerra Mundial (1914-1918). Passadas nove décadas do final da "Grande Guerra", como também ficou conhecida, considera-se pertinente ter um breve contato com modos de pensar, sentir e agir que antecederam o conflito, acompanhando ainda as mudanças que ele proporcionou em curto período.

Comecemos perguntando: em meados de 1914, por ocasião do início da guerra, quais as expectativas dos habitantes dos países envolvidos no conflito e como eles o percebiam? Questionamento que pode ter alguns esclarecimentos por intermédio de fontes não muito exploradas pelos historiadores, folheando-se, por exemplo, um álbum de fotografias do período, ou lendo as correspondências particulares de então, entre tantas outras. Documentos que registraram e comunicam sentimentos e representações os mais diversos em relação ao que se passava, e que tenderam a se modificar com o desenrolar da guerra.

No intuito de trazer algumas respostas a tais questionamentos, a proposta deste ensaio é construir uma narrativa - uma entre tantas outras possíveis - a partir de um álbum de retratos de família ${ }^{3}$ dos tempos da Primeira Guerra Mundial e das reflexões por ele suscitadas. Narrativa que não é nada mais que uma interpretação de determinada série arbitrariamente destacada do conjunto de registros fotográficos relacionados àquele conflito e pertencentes a um álbum que traz retratos das famílias Marinho de Azevedo, Seiffen e Gérard. Coleção precedida por uma árvore genealógica em que a data de nascimento mais recuada, entre os retratados, remete ao ano de 1836, e que contém registros fotográficos desde o final do século XIX até a década de 1940. Conjunto construído em solo europeu, em sua quase totalidade na Alemanha, e trazido ao Brasil junto aos pertences de uma família emigrada, o álbum foi adquirido pelo autor em leilão realizado no mês de outubro de 2008.

Registros produzidos para a fruição privada e não para a exposição pública, acompanhados de anotações a caneta, algumas sobre a superfície emulsionada (ver Fotografias 4, 5 e 7), em língua alemã e portuguesa, muitas vezes informando algo sobre o fotografado. Geralmente identificando-o e, menos 
frequentemente, trazendo alguma indicação sobre data, local e grau de parentesco.

No total, são 145 fotografias, algumas muito danificadas e/ou recortadas de forma irregular, afixadas com cantoneiras e, em muitos casos, com cola em seu verso, situação que, enquanto persistir, impossibilita o acesso a algumas anotações ali existentes. Entre elas, 38 trazem retratados em trajes militares dos tempos da Primeira Guerra Mundial, inclusive quatro cartões postais. ${ }^{4}$ Há ainda duas fotografias produzidas durante a Segunda Guerra Mundial (19391945) ou às suas vésperas.

Até o momento, foi possível identificar a autoria de apenas 14 fotografias, ${ }^{5}$ e as selecionadas para o presente estudo não trazem indicações a respeito. Desconhecer seus autores é, sem dúvida, um fator limitador do trabalho, ao se ter em conta a advertência de Sontag, segundo a qual "na medida em que a fotografia é (ou deveria ser) sobre o mundo, o fotógrafo conta pouco, mas na medida em que é o instrumento de uma subjetividade questionadora e intrépida, o fotógrafo é tudo". Afinal, a câmara não é, como pensavam os primeiros fotógrafos, uma máquina copiadora, pois não é ela que vê, que dá o foco (Sontag, 2004, p.104, 138).

O fotógrafo "compõe a fotografia com a realidade e desta se apropria, a fim de melhor mostrar a si próprio". Ele seleciona ou exacerba as "modalidades de ser dos atores sociais ou das situações fotografadas”. ${ }^{6}$ Através da fotografia ele se comunica, expressando ideias, emoções, sentimentos, valores, preconceitos, por vezes de forma involuntária. O mesmo é feito pelo fotografado, conforme se discutirá em seguida.

HistóRIA, FOTOGRAFIA, RETRATOS

A Foto-retrato é um campo cerrado de forças. Quatro imaginários aí se cruzam, aí se afrontam, aí se deformam. Diante da objetiva, sou ao mesmo tempo: aquele que eu me julgo, aquele que eu gostaria que me julgassem, aquele que o fotógrafo me julga e aquele de que ele se serve para exibir sua arte.

Roland Barthes (1984, p.27)

No presente estudo, e tendo por pressuposto que a fotografia não é apenas uma forma de expressão, mas um meio de informação e comunicação, pelos indícios nela presentes, o primeiro procedimento para sua análise foi a seleção de uma pequena parcela dos registros que compõem o álbum. Seleção arbitrá- 
ria, mas presa aos propósitos de proceder à sua leitura no contexto da Primeira Guerra Mundial, dando destaque àqueles que suscitavam reflexões sobre a expressão de sentimentos dos retratados, suas formas de vivenciar o conflito e as alterações por este operadas em suas vidas. Gesto inspirado nas reflexões de Miriam Moreira Leite, segundo a qual a fotografia de família:

Como é imóvel e estática, representa um tempo presente, um agora diante do qual o pesquisador é levado a reconstruir o que levou aquelas personagens a estar ali, assim, daquele jeito, naquele momento, para poder prever o desenlace, os momentos seguintes que podem vir a ser encontrados em outros instantes isolados, em outras fotografias. (Leite, 2001, p.37)

Os registros fotográficos foram tomados não apenas como uma imagem com a qual se procurou captar a realidade, ${ }^{7}$ mas como sua construção e/ou leitura, como meio de comunicação através de mensagens de caráter nãoverbal e forma de mostrar-se para si e para os outros: ao fazer pose, o fotografado não apenas fixa determinada postura, mas seleciona previamente os elementos que irão compor o seu retrato. Realiza, dessa forma, um trabalho social de produção de sentido, operado pelo fotógrafo e, não menos, pelo fotografado que faz pose diante da câmara (Barthes, 1984). Formas de expressão produzidas tendo em vista determinados usos, individuais e/ou coletivos, e que nos revelam pistas sobre diferentes maneiras de pensar, sentir e agir. Formas que não são, necessariamente, correspondentes às daquele que delas se apropria posteriormente. ${ }^{8}$

Considerada a fotografia como uma imagem e como uma forma de interação social e de comunicação, tem-se por pressuposto que seu significado mais profundo não se encontra necessariamente explícito, pois é imaterial, apesar do "realismo fotográfico da aparência" de que ela se reveste (Kossoy, 2001, p.117). Comunicação que não se realiza pela linguagem verbal do fotografado, mas, no caso de retratos, como se trata no presente estudo, através de outras formas de expressão: a corporal e a gestual, entre outras. Busca-se, portanto, identificar seu conteúdo e deduzir, ao menos parcialmente, o que não está visível, ou seja, as articulações do conteúdo interno com o externo às fotos (Leite, 2001, p.44).

Sendo assim, toma-se o retrato fotográfico como um produto social e cultural, concebido como documento e como monumento. Como registro, um fragmento que chega até nós oriundo de outros tempos, e como recurso apto a comunicar representações, ou seja, modos pelos quais indivíduos e grupos 
sociais representam a si e ao mundo. Representações elaboradas cultural/estética/tecnicamente, ${ }^{9}$ mais evidentes quando fixadas em retratos de corpo inteiro, valorizando a pose, como a quase totalidade das selecionadas para o presente estudo. Conforme proposto por Ana Maria Mauad, reportando-se às reflexões do historiador francês Jacques Le Goff:

parafraseando Jacques Le Goff, há que se considerar a fotografia, simultaneamente como imagem/documento e como imagem/monumento. No primeiro caso, considera-se a fotografia como índice, como marca de uma materialidade passada, na qual objetos, pessoas, lugares nos informam sobre determinados aspectos desse passado - condições de vida, moda, infraestrutura urbana ou rural, condições de trabalho etc. No segundo caso, a fotografia é um símbolo, aquilo que, no passado, a sociedade estabeleceu como a única imagem a ser perenizada para o futuro. Sem esquecer jamais que todo documento é monumento, se a fotografia informa, ela também conforma uma determinada visão de mundo. ${ }^{10}$

Sem esquecer, não menos, que, mesmo muito tempo depois de realizada, ela segue sendo interpretada, oscilando os seus significados, ${ }^{11}$ afinal a fotografia, seja em sua produção, seja em sua recepção, sempre dá margem a um processo de construção de realidades (Kossoy, 2002, p.42).

O presente ensaio não propõe nada além disso. Seu intento é expor uma interpretação possível de oito retratos selecionados entre quase uma centena e meia daqueles que compõem um álbum de família. Interpretação focada não na representação operada pelo fotógrafo, mas pelos fotografados, não menos importante, como destacado por Barthes (1984), uma vez que há cumplicidade entre o fotógrafo e o fotografado. Cumplicidade mais evidente nos registros posados, em que ambos revelam a intenção de fixar determinada representação social, durante o "gesto radical" de produção desse artefato cultural, dessa "fatia única e singular de espaço-tempo". ${ }^{12}$

Para interpretar tais representações, as fotografias são exploradas em busca de formas de comunicação não-verbal, registradas através de gestos, poses, olhares, expressões faciais, orientações do corpo, posturas, distância e distribuição espacial entre os indivíduos, organização e disposição dos objetos. ${ }^{13}$ Essas poses são analisadas em suas interações com três recursos expressivos nelas presentes: as vestimentas (verdadeiros prolongamentos do corpo), os objetos simbólicos e a ambientação, característicos das fotografias de estúdio. ${ }^{14}$

Compreendendo-se que tais formas de comunicação não-verbal empregadas para transmitir mensagens apresentam diferentes significados em dife- 
rentes sociedades e culturas, contextos e/ou períodos, circunstâncias e situações, são elas analisadas pelo método iconográfico/iconológico proposto por Kossoy $(2001 ; 2002)$. Ou seja, a partir de sua inserção e em contraponto com o contexto histórico em que foram produzidas; mediante o confronto entre o global e os pormenores (Leite, 2001, p.158), entre aqueles fragmentos e seu contexto mais amplo, entre o privado (o retrato de família) e a esfera pública. Procedimento a partir do qual pretende-se torná-las historicamente significativas, não para contar a história de determinada família, mas para pensar o impacto da Grande Guerra sobre a vida familiar na Europa, em dado tempo e espaço.

\section{Retratos de Quem Viveu os tempos Da Grande Guerra}

O vestígio da vida cristalizado na imagem fotográfica passa a ter sentido no momento em que se tenha conhecimento e se compreendam os elos da cadeia de fatos ausentes da imagem. Além da verdade iconográfica.

O século XX começou sob um clima de animosidade contínua entre as grandes potências da época, marcando os tempos finais da Belle Époque. Embora fosse assim, o período pode ser traduzido, de forma muito breve, como de euforia entre parcelas das classes abastadas da sociedade europeia e, não menos, brasileira, diante das promessas de progresso e modernidade que marcaram o século XIX.

O grande modelo civilizatório era a deslumbrante Paris, a "Cidade Luz", e a ideologia cientificista vivia seu apogeu, pois se acreditava que, com o auxílio da ciência, todos os problemas do mundo deveriam ser resolvidos. Na ciência era a Alemanha que se destacava, com suas universidades, escolas técnicas superiores e revistas especializadas. Sua influência se estendia para além da Europa, alcançando países como Estados Unidos e Japão. O desenvolvimento tecnológico era outro fator de deslumbramento. E a Grande Guerra, em que ainda houve o emprego de espadas, cavalos e pombos-correio, iria intensificálo ainda mais!

Documentos aparentemente banais, como uma correspondência sem maiores pretensões - esse 'documento essencial' que tende ao desaparecimento $^{15}$-, nos trazem mais pistas sobre a percepção daqueles que vivenciaram o grande conflito. Em breve correspondência datada de 16 de maio de 1915 e remetida da Noruega para Paranaguá, um tal de J. Jacobsen informava não 
pretender viajar para outros países "até a guerra acabar-se”, em sutil indicação de que acreditava que o conflito logo chegaria ao final. Em outra passagem, contava aos amigos deixados no Brasil que na cidade de Stavanger, onde fixara residência, existia "até cinematógrafo"! ${ }^{16}$ As incríveis imagens em movimento conquistavam aqueles que a elas tinham acesso!

Apesar do clima tenso entre os países europeus, sob tais circunstâncias, parcelas de suas classes abastadas esperavam que as coisas continuassem "caminhando bem", rumo à felicidade e ao progresso. Essa sensação também era revelada pelas fotografias, imagens que, estáticas, marcadas pela imobilidade no âmago do mundo em movimento (Barthes, 1984, p.15), podem nos transmitir inúmeras mensagens, embora de forma distinta daquelas das telas de cinema, que encantavam e seduziam as plateias desde as primeiras décadas do século XX.

Tanto era assim que, em um álbum repleto de retratos de uma família alemã daquele período, encontramos imagens de jovens soldados trajando uniforme militar, prontos para seguirem para a guerra como quem se preparava para um empolgante evento! Apesar da expressão facial serena e sem qualquer esboço de sorriso daqueles soldados, são imagens que remetem ao contexto da guerra que se iniciava, mas não à dor, ao sofrimento, destacando outros sentimentos e expectativas em relação a ela.

Segundo observou o historiador inglês John Keegan, no início do século $\mathrm{XX}$, ao se ter em vista a solução de conflitos, a política posta em prática pelos países europeus se pautava no fortalecimento do poder militar em detrimento de outros recursos. Naquele contexto, "havia, reconhecidamente, um medo abstrato da guerra. Entretanto, mais forte do que isso era o medo de falhar em face do desafio da guerra". ${ }^{17}$

Ainda assim, não se apostava na eclosão de um conflito duradouro e de grandes proporções. Aos olhos de hoje, pode parecer inacreditável, mas a expectativa mais corriqueira era por uma guerra breve e, até mesmo, entusiasmante! Sob tal perspectiva, a imagem que se divulgava era a de bravos e cavalheirescos soldados, que, em curto período, retornariam cobertos de glória e seriam recebidos como heróis!

De fato, o plano da Alemanha, com sua poderosa máquina militar no auge do poderio, era derrotar com rapidez a França e, logo a seguir, a Rússia. Segundo relatos do período, após a corrida para o alistamento, a partida dos soldados aconteceu em meio a um clima festivo, com as mulheres depositando flores nas suas armas (Keegan, 2004)! Contudo, e isso logo se tornaria patente, 
o desenrolar da guerra foi bem diverso daquilo que inicialmente se previa, tomando rumos bem mais dolorosos.

Do lado francês, o que se observava não era muito diferente. A ponto de seus combatentes seguirem para os campos de batalha trajando vistosos uniformes, com calças vermelhas. A cavalaria, por sua vez, portava capacetes guarnecidos de plumas e cintilantes peitorais de aço. Verdadeiros trajes de gala, resquícios do século XIX, usados por homens que não imaginavam o que os esperava! $!^{18}$

Se as coisas se passavam mais ou menos dessa forma, antes de seguir para a frente de batalha, o jovem alemão Ferdinand ${ }^{19}$ vestiu seu uniforme militar de oficial carabineiro e fez pose, ou seja, assumiu uma postura estudada e artificial, para duas fotografias. Era o momento de registrar sua imagem para a posteridade. Uma delas foi produzida no interior de um estúdio (Fotografia 1), onde era costume, desde meados do século XIX, compor uma cena para a pose do retratado. Desta podiam fazer parte móveis, cortinados, painéis e objetos variados, disponíveis nos estúdios fotográficos.

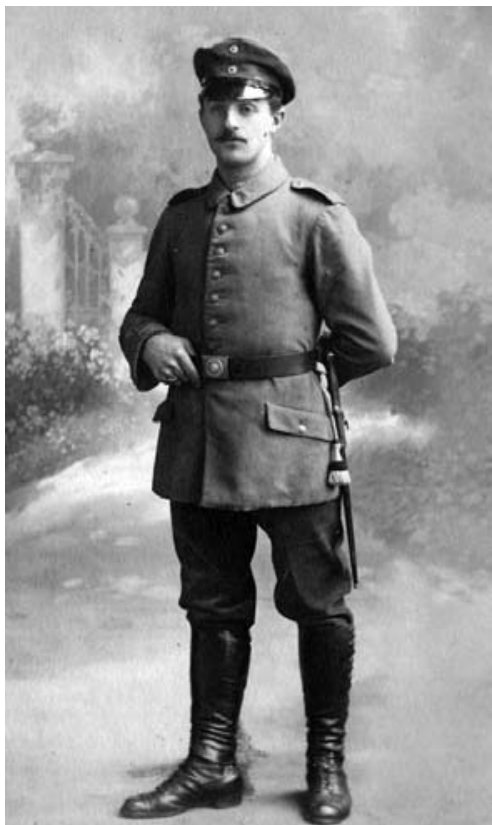

Fotografia 1

Ferdinand faz pose em estúdio fotográfico, $1914.14,0 \times 9,0 \mathrm{~cm}$

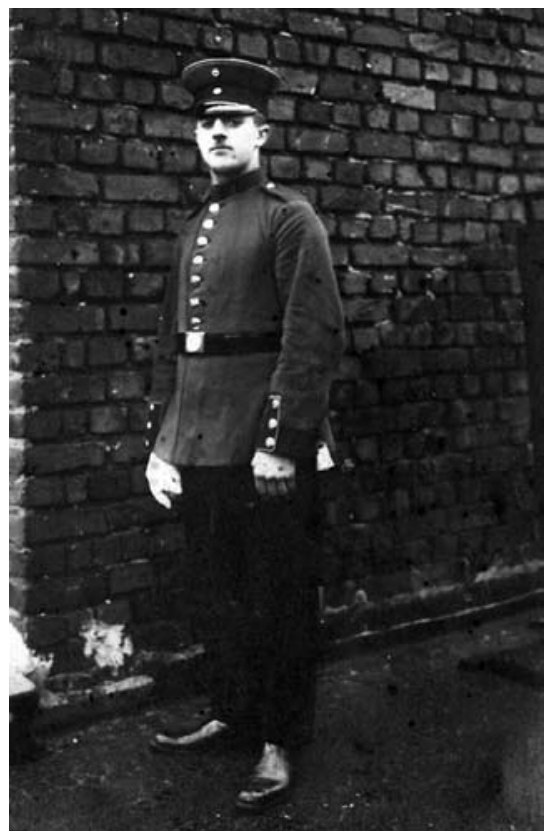

Fotografia 2

Ferdinand e a parede de tijolos, sem data. $14,0 \times 9,0 \mathrm{~cm}$ 
No caso da representação visual de "Ferdi", como também era chamado na intimidade, o cenário para o cerimonial fotográfico (Barthes, 1984, p.24), cuja seleção tinha a função de "valorizar o retratado" (Moura, 1983, p.120), era uma bucólica e tranquila paisagem romântica repleta de flores, que contrastavam surpreendentemente com sua postura ereta, tranquila, mas austera. Essa foi a sua opção ao encenar para a posteridade, incorporando um homem das armas. Uma escolha intencional que contrasta com a guerra e a violência que a caracteriza, documentando e monumentalizando um instante, de forma que agora nos oferece pistas sobre como foi percebido e vivenciado por aquele e outros atores sociais.

Já não era, é bem verdade, o retrato repleto de objetos e acessórios, como se costumava fazer no século XIX. Mas se trata, sem dúvida, de uma teatralização ainda inserida naquele espírito de fazer a representação de determinado papel social. De tal forma, a performance de Ferdinand em um cenário ilustra bastante bem uma tendência observável nos retratos fotográficos produzidos em estúdio, qual seja, a de registrar não necessariamente uma 'realidade social', mas sim 'ilusões' ou 'fantasias' sociais. ${ }^{20}$

Já se sugeriu que jardins e flores presentes em retratos produzidos em estúdios fotográficos seriam sinônimo de delicadeza (Koutsoukos, 2007, p.17). No caso de Ferdinand, contudo, propõe-se algo distinto. Em busca de uma possível explicação para a opção por uma ambientação tão singela e florida para a pose de um militar, tem que se ter em conta que, se a guerra havia chegado, Ferdinand posava como se fosse um guardião do bem-estar, da tranquilidade, enfim, da paz! Postado à frente do portal de um jardim, era como se ele, com seu ar sereno, sua postura ereta e confiante, fizesse o papel de responsável por zelar pela paz e tranquilidade representadas pelo cenário.

Por isso, no retrato, ele permanecia estacado na estrada imaginária que conduzia ao jardim florido e murado. Para alcançá-la seria inevitável passar pelo soldado ali postado, cuja imagem se desenhava em primeiro plano, como um obstáculo que não apenas barrava o acesso, como a visão daquilo que vinha além.

Misto de sensibilidade e força, o retrato posado procurava convencer que Ferdinand estaria a serviço da paz. Nem que para isso fosse obrigado a fazer uso da força e, no limite, matar o inimigo...

No álbum, a expressão tranquila e serena da imagem de estúdio foi fixada ao lado de outra (Fotografia 2), onde a perspectiva vertical ascendente assumida pelo fotógrafo permitia a Ferdinand fixar o olhar de cima para baixo, trazendo a impressão de poder, segurança e confiança. ${ }^{21} \mathrm{~A}$ força e o poder 
expressos pelo retratado eram reforçados pela presença de uma parede com os tijolos expostos. Esta lhe servia de fundo e emprestava à imagem um ar pesado e austero, cuja escuridão contrastava profundamente com a claridade, transparência e leveza da imagem anterior, realizada em estúdio. Ao mesmo tempo, o paredão pesado e sombrio não permitia vislumbrar qualquer possibilidade de ir além, de prosseguir, diferindo novamente da outra fotografia, que dava a impressão de profundidade e amplidão.

Em ambos os retratos de Ferdinand em uniforme militar ficava estampada a imagem de quem estava prestes a lutar pela sua pátria, esforçando-se para imortalizá-la de forma nobre, com a melhor aparência possível, naquele momento de posar para homenagear a si próprio. O contraste entre os claros e os escuros daqueles registros se acentua com sua presença, lado a lado, na forma como foram incorporados ao álbum fotográfico. Retratos fotográficos que confirmam as proposições de Ana Maria Mauad, que os associa à necessidade de não apenas ressaltar a individualidade do fotografado, como ainda inscrevê-lo em determinada identidade social. ${ }^{22}$

Explorando o álbum, constatamos que vários parentes de Ferdinand posaram para fotografias em trajes militares usados na Grande Guerra. Aparentando ser bem mais jovem, Hermann compareceu com dois retratos em uniforme militar germânico, posicionando-se em meio perfil. Em um deles, empunha um fuzil na mão direita, à altura da cintura (Fotografia 3). Como nos registros de Ferdinand, trata-se de imagens de corpo inteiro, com expressão facial sem qualquer esboço de sorriso, muita pose e quase nenhuma espontaneidade. Lábios ligeiramente comprimidos, expressando firmeza de propósitos, segundo Weil e Tompakow (2007). Ao fundo da cena, novamente se observa a presença de vegetação. Mas desta vez não se tratava do cenário de um estúdio fotográfico, pois os retratos foram produzidos ao ar livre.

Neste caso, contudo, fica uma pergunta, por conta de sua aparência extremamente jovem: seria ele, de fato, um dos muitos soldados ainda adolescentes que tomaram parte no conflito? Ou, em um momento no qual a ênfase no militarismo estava em alta e o exército alemão era o modelo para os demais, Hermann teria simplesmente vestido uma farda - que parece um pouco grande - para fazer apologia ao militarismo e à guerra? Ou seja, teria produzido intencionalmente não apenas um documento, atestando ser ele um jovem militar, como os descritos por Remarque (1974), mas também um monumento, firmando seu apoio àqueles que seguiam para a guerra e - quem sabe? - o seu propósito de imitar-lhes o exemplo. Não se sabe. 


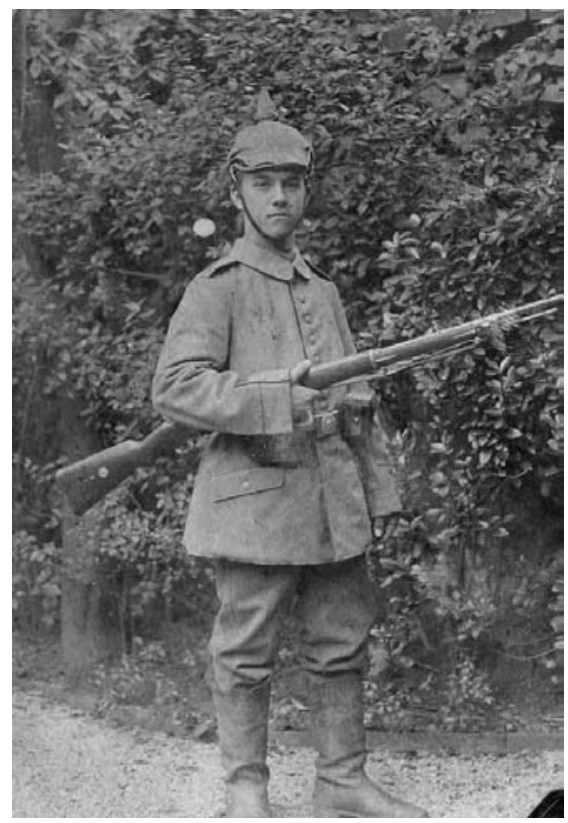

Fotografia 3

O jovem Hermann faz apologia ao militarismo, 1915. 12,5 x 9,0 cm

Tanto Ferdinand como Hermann optaram pelo retrato individual. Nele, representavam um determinado papel social de destaque: o de militar. E assim realizavam uma encenação, travestindo-se de forma a registrar e perpetuar uma imagem de si como um militar que, na condição de oficial ou soldado raso, estava, ou talvez desejasse estar, a caminho da guerra. Um momento único que, uma vez captado, perpetuaria algo que pretendiam mostrar aos seus contemporâneos e às gerações futuras.

Não são imagens de quem está no campo de batalha, mas fotografias de quem, no contexto da guerra, fez pose de militar. Esse personagem era, então, ao mesmo tempo, extremamente valorizado, pois representava o braço armado a defender seu país, e extremamente desvalorizado, seguindo para a morte aos milhões, muitos sem compreender por quê, como se observou no correr da Primeira Guerra Mundial.

Mas ambos fazem apologia à guerra. Não questionam, antes a reafirmam e a reconhecem como legítima, mostrando-se dispostos a dela tomar parte, dar sua contribuição. Ao mesmo tempo, afirmam uma identidade: a de um indivíduo do sexo masculino, um militar nascido na Alemanha e a seu serviço. 
Outro membro da família a figurar no álbum em trajes militares foi Anton Hermann. São várias fotos suas na companhia de sua esposa Frieda Elizabeth, com quem se casou no início de 1914. E também com seus filhos, Maria Christine, ou "Mia", nascida em outubro de 1914, e Hermann Hans, nascido no início de 1917 (Fotografia 4). Esposa de Anton, Frieda era irmã de Hermann e, possivelmente, de Ferdinand (Fotografias 1, 2 e 3).

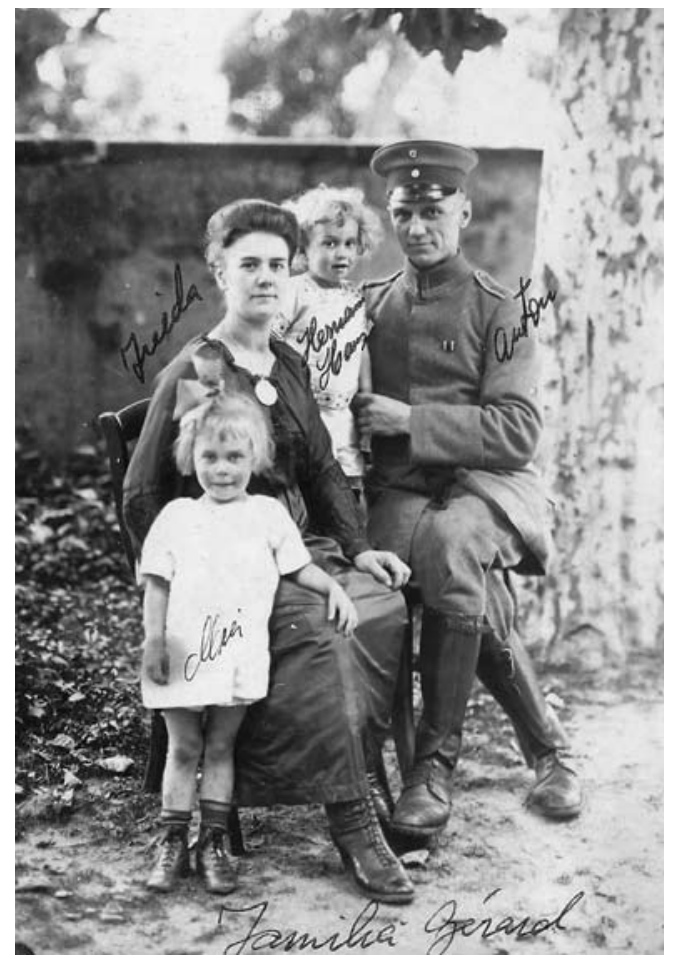

Fotografia 4

Anton, Frieda e seus filhos, 1918. 14,0 x 9,0 cm

Nos retratos, Anton, que, conforme narrado, teve um período pleno de acontecimentos no correr da guerra, se apresentava habitualmente trajando uniforme militar: ao telefone, ao lado de outros militares, ou na convivência com a família: nos momentos de lazer, amparando o filho nos seus primeiros passos em uma propriedade rural, e em outras situações em que, à semelhança de retratos anteriores (Fotografias 1 e 3), a vegetação estava presente, servindo de cenário. 
Nas cenas familiares, além da tranquilidade do lar, evidenciava-se que esposa e filhos estavam sob a guarda e a dependência de um membro das forças armadas. Registrados, portanto, os papéis sociais do militar e da família. Representação/exibição de poder e de um determinado pertencimento, na vida privada e social. Na representação familiar apresentada na Fotografia 4 permaneceram todos muito próximos, esboçando um ligeiro sorriso e formando um bloco compacto em que se apoiam e protegem reciprocamente. $\mathrm{O}$ filho mais jovem, com um ano de idade, permanece entre os pais, apoiado por Anton e assumindo a posição central, sobre a cadeira ocupada por Frieda, para compensar sua pequena estatura. A filha, então contando quatro anos de idade, é a mais exposta, posicionando-se à frente de todos.

É tentador especular em torno da hierarquia expressa pela composição da imagem, que, em um rápido relance do olhar, parece dar igual importância a todos os membros do grupo familiar. Contudo, ao aparecer em primeiro plano, paradoxalmente Mia tem sua relevância reduzida, pois ocupa a posição mais baixa, sendo seguida por sua mãe, a segunda personagem feminina da cena. Em escala ascendente, seguem os representantes do sexo masculino, Hermann e, finalmente, no topo, Anton.

Posando para a fotografia, o grupo provavelmente encenou, de forma talvez involuntária, a representação social percebida como adequada, em que o homem, que também é militar, ocupa a mais alta posição, e o filho Hermann, mesmo ainda criança, está acima da mãe, cujo sexo a relega a um papel de menor prestígio social.

Apesar disso, ao se focar a imagem de Frieda constata-se que ela assumiu uma postura ereta, que expressa confiança, altivez e sobriedade. Características acentuadas pelo traje escuro e pelos cabelos presos. Talvez de forma mais explícita que o esposo militar, cujo olhar não é tão firme quanto o da esposa e cuja perna esquerda, ligada à emoção, está cruzada sobre a direita, a da razão, se dermos crédito às conclusões de Weil e Tompakow (2007) em relação à postura corporal e seus significados. Provavelmente, Anton não conseguiu ocultar por completo a sensação de conforto experimentada no refúgio familiar, quando estava temporariamente afastado da guerra. É como se expressasse, com seu corpo, e sem pronunciar nenhuma palavra, aquilo que estava sentindo no momento.

Ao final do álbum, duas fotografias, uma com a anotação “1938” em seu verso, outra sem menção a data, remetem a um conflito de maiores proporções, a Segunda Guerra Mundial, ou às suas vésperas. Em ambas, a suástica nazista está presente. Sobre uma delas, estampada uma anotação: "H. Hans" (Fotogra- 
fia 5). Seria o filho de Anton e Frieda fazendo parte dos quadros nazistas, décadas após, que aparecia enquadrado no canto inferior da fotografia, posando em meio perfil e encarando a lente do fotógrafo?

Há grande possibilidade de a resposta ser afirmativa, pois o álbum de fotografias em questão possivelmente pertenceu a um filho de Anton e Frieda, responsável por muitas das anotações que identificam os fotografados. Na Fotografia 5, ao lado da inscrição "H. Hans", há a observação "irmão", o que torna plausíveis as suposições sobre o retratado ser Hermann Hans, ainda muito jovem, e a autora de algumas legendas ser Maria Christine. ${ }^{23}$

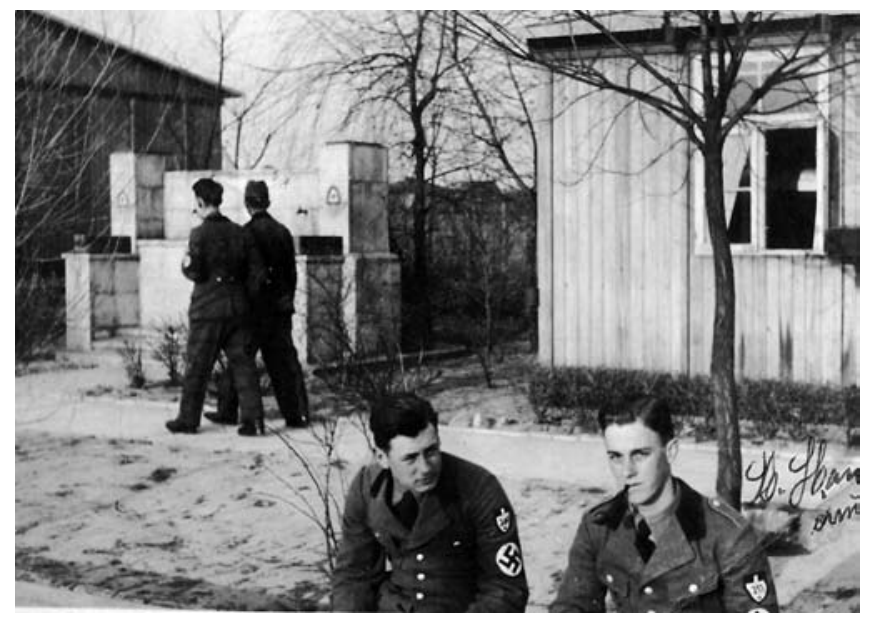

Fotografia 5

H. Hanns (de cachimbo): filho de Anton e Frieda?, sem data. 8,0 x 11,5 cm

Seja qual for a resposta, mais uma vez algum membro daquela família pode ter tomado parte em um conflito de caráter mundial e diretamente ligado à Grande Guerra de 1914-1918, pois a conflagração seguinte foi o desdobramento trágico da primeira. Os tratados, os acordos, as sanções e todas as consequências que estes trouxeram ao povo alemão no período entre guerras têm estreitas relações com o que se seguiu.

Retornemos ao início da guerra, em 1914, quando, embora possa parecer inverossímil, os britânicos não perceberam com bons olhos o emprego de metralhadoras, por julgá-las excessivamente letais! E o que dizer dos primeiros aviadores que, como verdadeiros cavalheiros, cumprimentavam os pilotos inimigos (Neves, 2004; Keegan, 2004)? 
Até então, ninguém era capaz de imaginar que o que aguardava os combatentes, em curto período, era uma grande carnificina de homens confinados em trincheiras fétidas e cheias de piolhos. Nelas, tentava-se sobreviver em meio às doenças, à lama, ao frio, à fome e à falta de água e medicamentos. Situação ainda mais insuportável em razão da presença sempre próxima do inimigo e de cadáveres insepultos, que eram devorados pelos ratos! Nesse contexto, pensar em vitória passou a ser simplesmente vislumbrar a possibilidade de sobreviver e retornar para casa sem grandes sequelas físicas ou emocionais.

Onde estava o glamour de tudo isso, e de que forma tal situação correspondia às imagens dos retratos do álbum de família? Pode-se afirmar que em absolutamente nada! A dura realidade da guerra - do novo tipo de guerra que não poupava nem mesmo aos civis - aos poucos iria se tornando patente, em meio ao conflito que, no dizer do historiador inglês Eric Hobsbawm (1995), assinalou o colapso da civilização ocidental do século XIX e deu início ao "Breve Século XX", "o século mais assassino de que temos registro". Afinal, prossegue Hobsbawm, 1914 inaugurou a "era do massacre”. A partir de então os civis e a vida civil tornaram-se alvos certos, quando não preferenciais da guerra dirigida aos não-combatentes.

Já não era mais possível idealizar o conflito, e não havia mais motivos para entusiasmo diante do seu prosseguimento. As cenas da guerra real, travada em meio ao sangue e ao sofrimento que marcaram o século $\mathrm{XX}$, iriam contrastar profundamente com aqueles "retratos quase inocentes", como talvez os qualificaria o estudioso e colecionador de fotografias Carlos Marcondes de Moura (1983). Retratos que, no caso de Anton, podem ter funcionado como recurso para perenizar as ocasiões em que pôde fugir ou se afastar, ao menos momentaneamente, dos horrores da guerra, que dia após dia tornavam-se mais manifestos.

Sentimentos que parecem estar presentes em outro registro fotográfico. Folheando novamente o álbum, deparamos com uma fotografia em tom sépia de Frieda Elizabeth, esposa de Anton. Imagem captada no interior de uma residência, mas tão posada que lembra muito uma fotografia realizada em ambientação de estúdio. Isso, apesar do excesso de móveis e objetos que lhe servem de cenário e denunciam o espaço doméstico. Diferindo dos demais registros selecionados, Frieda não encara a câmara, mas tem o olhar perdido durante a realização do cerimonial fotográfico em que ocupou o centro da cena. Seu ar pensativo, distante, algo desnorteado (Fotografia 6), parece tender para a sensação de insegurança, tristeza e absoluta desilusão. Sentimentos que, 
após 1914, substituíram a euforia da Belle Époque que se findava, dando início ao "Breve Século XX".

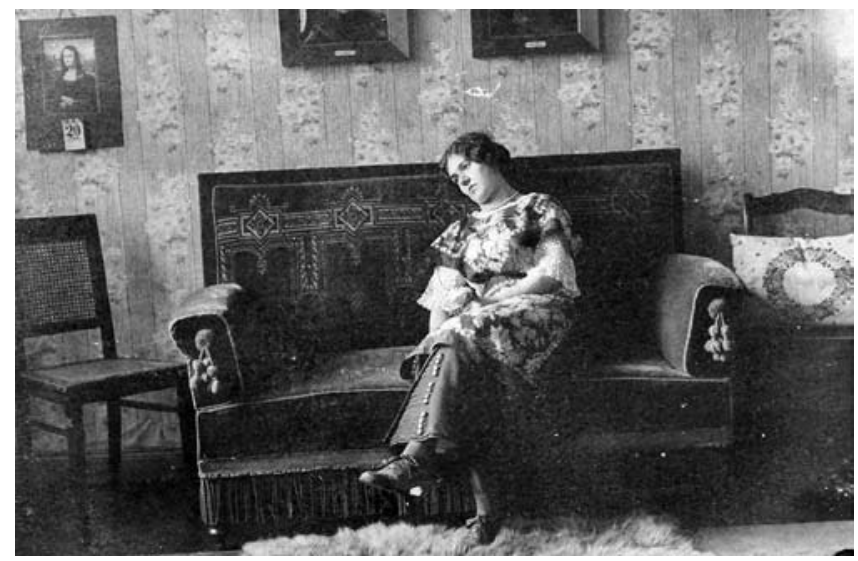

Fotografia 6

Frieda não olha para a câmara fotográfica, sem data. 9,0 x 14,0 cm

Sentimentos expressos pela linguagem corporal de Frieda, através de sinais como o ar de indiferença, apatia, os olhos baixos, o corpo largado e o isolamento (Dimitrius; Mazzarella, 2000, p.76). E desta feita é Frieda que sobrepõe a perna esquerda (a da emoção) sobre a direita (a da razão). Postura que contrasta profundamente com a segurança e altivez expressas na Fotografia 4, em que se apresentou confiante, servindo de apoio a ambos os filhos. Naquele momento, seu olhar expressava segurança, até mesmo se comparado com o de seu esposo Anton, conforme já destacado.

Em outro retrato, provavelmente produzido na mesma ocasião, Frieda fez pose ao lado de duas mulheres (Fotografia 7). O fotógrafo afastou-se talvez um passo, obtendo uma visão mais ampla do cenário, que permanece o mesmo da fotografia anterior (Fotografia 6). Sentadas no sofá, todas mantêm o olhar dirigido à sua direita. Estariam olhando em direção à porta (que não aparece), à espera de alguém? O marido, filho, irmão, ou algum parente e/ou amigos que estariam nos campos de batalha, como Frieda exemplificava tão bem?

Em ambas as fotografias, o sofá é ladeado por duas cadeiras vazias (uma delas ocupada por uma almofada), que também parecem aguardar por alguém. Ao fundo o papel de parede florido, e a bata vestida por Frieda também é coberta por motivos florais. Novamente as flores surgem na ambientação. 


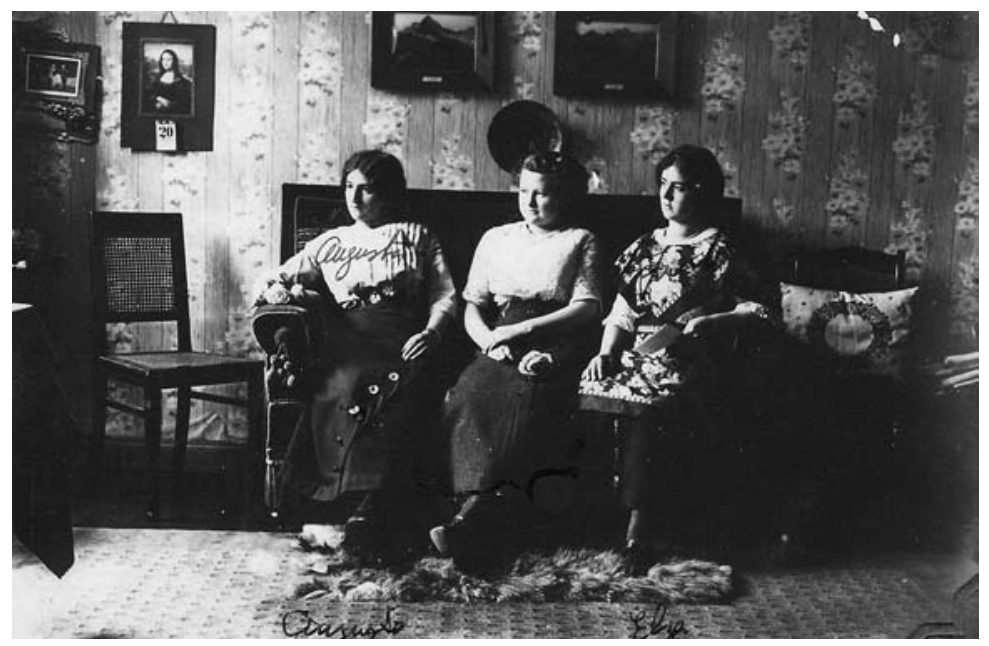

Fotografia 7

À espera de alguém?, sem data. 9,0 x 14,0 cm

Ao lado das outras mulheres, Frieda tem em sua mão esquerda o que parece ser uma carta ou, talvez, uma fotografia. As demais, na mão direita, seguram uma rosa de tons claros. Na pose individual, o objeto desaparece das mãos de Frieda.

O refúgio doméstico, escolhido por Frieda e pelas mulheres que posaram ao seu lado, parece ter se transformado no espaço da solidão e da espera, experimentadas por elas e outras esposas e mães do período.

Os dois retratos no sofá, em sua encenação, em certa medida ilustram o estado de espírito daqueles que vivenciaram a dramática experiência da Grande Guerra e tiveram de enfrentar suas duras consequências nos anos que se seguiram. Momento em que se tornara raro ter notícias de famílias europeias “sem viúvas, órfãos, grandes mutilados". E logo ficaria claro que aquela não seria a última guerra, apesar de tão grande sacrifício e tantas atrocidades, em meio a uma luta de morte que prosseguiu até a exaustão completa dos beligerantes, arruinando vencedores e vencidos (Prost; Vincent, 1994, p. 212-213; Hobsbawm, 1995, p.37-38).

Mais à frente Frieda reaparece no álbum com os filhos e o marido, em retrato extremamente desbotado - por isso não reproduzido. As crianças cresceram, e ele comparece em trajes civis. Estão todos defronte a um grande arbusto, que lembra o cenário escolhido pelo jovem Hermann (Fotografia 3). Anton está sentado em uma cadeira, com o filho no colo. A menina Mia e a 
mãe permanecem em pé. Frieda se posiciona ligeiramente atrás do esposo e apoia a mão direita no encosto da cadeira de Anton. O casal, sobretudo Frieda, esboça um ligeiro mas inegável sorriso.

A família reunida, a vestimenta de Anton, um leve sorriso... A fotografia não traz indicação do ano em que foi tirada, mas tudo nela faz crer que estavam, ao menos momentaneamente, distantes da guerra. Ou teria ela terminado?

\section{CONSIDERAÇÕES FINAIS}

... tanto o documento escrito quanto as imagens iconográficas ou fotográficas são representações que aguardam um leitor que as decifre.

Miriam Moreira Leite (2001, p.23)

Destino perverso esse da fotografia que, num dado momento, registra a aparência dos fatos, das coisas, das histórias privadas e públicas, preservando, portanto, a memória desses fatos, e que, no momento seguinte, e ao longo de sua trajetória documental, corre o risco de significar o que não foi.

Boris Kossoy (2005, p.39)

Oito retratos fotográficos em preto e branco. Oito diferentes cenários e situações nos quais o sorriso esteve invariavelmente ausente, esboçando-se sutilmente em apenas um deles. Entre outros motivos, porque aqueles eram tempos de guerra. Mas também porque era exatamente assim que se comparecia diante de uma câmara fotográfica para tão importante cerimonial de composição de uma representação visual. Sete também são registros nos quais houve extremo cuidado com a pose. Talvez a única exceção seja o retrato não pertencente ao contexto da Primeira Guerra, a fotografia de número 5, um instantâneo amador, denunciado pelo enquadramento e pelo corte dos corpos.

Naqueles retratos, Ferdinand, Frieda, Hermann e os demais fotografados, personagens estáticos e mudos, monumentalizaram uma representação. Legaramnos documentos que são monumentos. Exemplos exacerbados da monumentalização de representações, verdadeiros paradoxos entre o 'real' e o imaginário, se colocados em contraponto com a carnificina ocorrida nas trincheiras da Grande Guerra.

A encenação que caracteriza as fotografias, apesar de produzidas para circular no contexto da intimidade familiar, revelam, mesmo assim, leituras 
do mundo e encenações de si. Os retratos do álbum de família, congelando um instante, uma pose, uma mensagem, apresentavam recortes e escolhas capazes de nos colocar em contato com representações muito particulares do período em que foram produzidas, esboçando interpretações singulares do mundo, denunciadas pela linguagem não-verbal dos retratados, em toda sua riqueza e complexidade.

É lícito propor, portanto, que aqueles retratos revelam muito mais que detalhes da moda e das vestimentas, do mobiliário, das construções, dos armamentos, ou de circunstâncias ligadas exclusivamente àquele grupo familiar, pois permitem ter acesso a formas de ser e agir daquele contexto. Afinal, uma chapa fotossensível, mais que capturar a realidade, fixa determinada interpretação do mundo produzida por aquele que é fotografado e por aquele que aperta o botão da máquina. Fixa, na superfície emulsionada de uma fotografia, não necessariamente aquilo que eles eram, mas aquilo que queriam ou pretendiam ser. "Já se disse que o retrato é uma representação de alguém que sabe que está sendo fotografado" (Leite, 2001, p.97). Fala sobre como queriam ser percebidos e sobre como percebiam o mundo do qual faziam parte.

O fotógrafo seleciona, enquadra, recorta, escolhe o ângulo, enquanto o fotografado, ao se perceber focado, faz pose: postura ereta e peito estufado, como convém a um militar; olhar tranquilo dirigido ao obturador, ou a um ponto qualquer... No entanto, antes da pose o fotografado já selecionou o traje, os objetos e o ambiente e já fixou a postura e o gestual considerados mais adequados. Isto é, durante o cerimonial, realiza uma encenação de si, de forma que a imagem captada pela chapa fotográfica seja o mais parecida possível com aquilo que ele deseja ser, na forma como deseja ser, embora não necessariamente correspondente àquilo que é: mais jovem, mais alto, menos gordo, sorridente, bem-sucedido... Sempre dando margem a renovadas leituras, pois, se a imagem registrada não se modifica, está sempre sujeita a interpretações, a cada vez que um olhar lhe é dirigido.

Quanto ao álbum familiar, pode-se afirmar, sob o apoio de diversos estudos, que habitualmente é construído na forma de uma crônica das coisas boas da vida. ${ }^{24}$ Talvez até mesmo quando fala dos tempos de guerra. Os combatentes comparecem, mas os aspectos terríveis do conflito ficam de fora. Quase todas as fotografias confirmam tais assertivas. Mas a solidão e o olhar distante de Frieda (Fotografia 6) nos advertem de que a vida também tem momentos de dor, de angústia, de incerteza. Seu olhar perdido rompe, em certa medida, com essa tendência dos álbuns de família de adocicar a vida com fotografias mais suaves. E assim, na intimidade do lar e sob um ponto de vista muito 
particular, Frieda nos remete àquilo que se passava no mundo de então e ao drama da Grande Guerra que deu início ao "Breve Século XX”.

Por isso, os retratos de Frieda sentada no sofá, assim como os demais, todos pertencentes ao contexto da guerra, podem ter, no momento de sua produção, expressado sentimentos muito diversos daqueles aqui propostos. Mesmo tendo marido e irmãos envolvidos no conflito. E assim se reafirma que, "através da fotografia aprendemos, recordamos, e sempre criamos novas realidades” (Kossoy, 2005, p.36). Sua interpretação, além de múltipla, é sempre subjetiva, pessoal. Pode então parecer mais seguro o seu emprego apenas como ilustração, como habitualmente se faz na pesquisa historiográfica. Mas ela exige mais, devendo suscitar reflexões que obriguem ao historiador ir além.

Em outras palavras, se lhe dirigirmos um olhar inquiridor, torna-se irresistível ler para além daquilo que a imagem fotográfica em si apresenta explicitamente. A encenação que dá vida àqueles retratos em nada inocentes nos conduz aos medos, incertezas, expectativas, alegrias, tristezas, e tantos outros sentimentos mais ou menos ocultos de homens e mulheres fotografados e que há muito se foram. E, não menos, aos daqueles que, mesmo passadas muitas décadas, deles se apropriam, dando-lhes renovadas interpretações, pois há uma interação entre as características do objeto e daquele que o observa (Leite, 2001, p.145).

Essa encenação, essas poses, esse fabricar-se instantaneamente como imagem são como a teia, que esconde e, por isso mesmo, pode revelar a aranha. Isso força o historiador a perguntar, sempre que depara com uma fotografia, ou outro documento qualquer: quem está dizendo o quê, de que forma, por quê, para quem, em que contexto? Porque ela não apenas registra um instante com uma imensa aparência de realidade, mas, possibilitando uma interpretação subjetiva, suscita reflexões, e sua leitura é sempre histórica.

\section{NOTAS}

${ }^{1}$ BARTHES, Roland. A câmara clara: nota sobre a fotografia. Rio de Janeiro: Nova Fronteira, 1984. p.22-23.

${ }^{2}$ SONTAG, Susan. Sobre fotografia. São Paulo: Companhia das Letras, 2004. p.19, 127128.

${ }^{3}$ Nas palavras de Mauro Koury, o álbum fotográfico familiar é um "instrumento privado em que se depositam as lembranças iconográficas familiares, de amigos próximos e pessoas importantes que, de forma direta ou indireta, estiveram presentes na vida e na organização familiar" (KOURY, Mauro G. P. Fotografia e interdito. Revista Brasileira de Ciências Sociais, São Paulo, v.19, n.54, p.129-141, fev. 2004. p.131-132). Segundo Susan Sontag, por 
intermédio de fotografias, "cada família constrói uma crônica visual de si mesma - um conjunto portátil de imagens que dá testemunho da sua coesão" (SONTAG, 2004, p.19). Por sua vez, Eder Chiodetto percebe tais álbuns como "uma edição em ritmo de filme açucarado de sessão da tarde, em que todo o atrito, tudo o que impeça a felicidade plena, deve ser extirpado. Amnésia para os momentos infelizes e eternidade para a felicidade, essa é a lógica que permeia os álbuns de família" (CHIODETO, Eder. Coleções de casamentos, nascimentos, aniversários. In: ITAÚ CULTURAL. Enciclopédia de artes visuais. Disponível em: www.itaucultural.org.br; Acesso em: 10 nov. 2008). Miriam M. Leite também destaca a exclusão de conflitos e hostilidades nessa autorrepresentação das famílias, que, ao mesmo tempo, focam a hierarquia, a dignidade, a estabilidade. E acrescenta: "como a fotografia é utilizada para reforçar a integração do grupo familial, reafirmando o sentimento que tem de si e de sua unidade, tanto tirar as fotografias, como conservá-las ou contemplá-las emprestam à fotografia de família o teor de ritual de culto doméstico". A autora também adverte que não é toda a vida que é fotografada para fazer parte de um álbum de família, pois uma fotografia é resultado de uma seleção (LEITE, Miriam Moreira. Retratos de família: leitura da fotografia histórica. 3.ed. São Paulo: Edusp, 2001. p.78, 87, 95). Tais afirmações corroboram as conclusões do pesquisador colombiano Armando Silva, segundo o qual não há álbum de família isento da intenção de contar uma história (SILVA, Armando. Álbum de família: a imagem de nós mesmos. São Paulo: Ed. Senac, 2008. p.23).

${ }^{4} \mathrm{~A}$ presença de cartões postais que remetem à guerra e/ou fazem apologia ao militarismo, mantidas junto às fotografias de familiares, evidencia sua relevância para aquele que as preservou. Relevância perceptível ainda em dois retratos de soldados, ladeados pela observação "não são parentes".

${ }^{5}$ Foto Samson comparece com cinco fotografias; Frohsinn, com três; Carl Fellner, Hoven e Alboldin, com uma. Fotografia Vahlendick figura com três cartões postais. Parece razoável supor que existam mais fotografias produzidas por Foto Samson, uma vez que o sobrenome aparece entre parentes com retratos incorporados ao álbum.

${ }^{6}$ CANABARRO, Ivo. Fotografia e cultura fotográfica. Estudos Ibero-Americanos, Porto Alegre, v.31, n.2, p.23-39, dez. 2005. p.32.

${ }^{7}$ Segundo Boris Kossoy, "A imagem fotográfica pode e deve ser utilizada como fonte histórica. Deve-se, entretanto, ter em mente que o assunto registrado mostra apenas um fragmento da realidade, um e só um enfoque da realidade passada: um aspecto determinado. Não é demais enfatizar que este conteúdo é o resultado final de uma seleção de possibilidades de ver, optar e fixar um certo aspecto da realidade primeira" (KOSSOY, Boris. Fotografia e história. 2.ed. rev. São Paulo: Ateliê Editorial, 2001. p.107). Por sua vez, ao propor que "fotos fornecem um testemunho", Sontag defende que há que se ter em conta que, "embora em certo sentido a câmera de fato capture a realidade, e não apenas a interprete, as fotos são uma interpretação do mundo tanto quanto as pinturas e os desenhos". E, mais adiante: "contudo, a representação da realidade pela câmera deve sempre ocultar mais do que revela" (SONTAG, 2004, p.16, 17, 34). Para uma breve proposta de crítica da fonte fotográfica, consultar: BURKE, Peter. Como confiar em fotografias. Folha de S. Paulo, 4 fev. 2001, Caderno Mais!, p.13. 
${ }^{8}$ CARDOSO, Ciro F.; MAUAD, Ana Maria. História e imagem: os exemplos da fotografia e do cinema. In: CARDOSO, C. F.; VAINFAS, R. Domínios da história: ensaios de teoria e metodologia. Rio de Janeiro: Campus, 1997.

${ }^{9}$ KOSSOY, Boris. Realidades e ficções na trama fotográfica. 3.ed. São Paulo: Ateliê Editorial, 2002; SAMAIN, Etienne (Org.). O fotográfico. São Paulo: Senac, 2004.

${ }^{10}$ MAUAD, Ana Maria. Através da imagem: fotografia e história - interfaces. Tempo, Rio de Janeiro, v.1, n.2, p.73-98, dez. 1996. p.80. Para a problemática documento/monumento, consultar LE GOFF, Jacques. Documento/Monumento. In: ROMANO, R. (Dir.). Enciclopédia Einaudi. v.1 - Memória, História. Lisboa: Impr. Nacional/Casa da Moeda, 1984. p.95-106.

${ }^{11}$ KOSSOY, Boris. O relógio de Hiroshima: reflexões sobre os diálogos e silêncios das imagens. Revista Brasileira de História, São Paulo, v.25, n.49, p.35-42, 2005. p.39.

${ }^{12}$ DUBOIS, Philippe. O acto fotográfico. Lisboa: Veja, 1992. p.163.

${ }^{13}$ SILVA, Lúcia Marta Gianta da et al. Comunicação não-verbal: reflexões acerca da linguagem corporal. Revista Latino-Americana de Enfermagem, Ribeirão Preto, v.8, n.4, p.5258, ago. 2000; RECTOR, Mônica; TRINTA, Aluízio Ramos. Comunicação do corpo. 4.ed. São Paulo: Ática, 1999; WEIL, Pierre; TOMPAKOW, Roland. O corpo fala: a linguagem silenciosa da comunicação não-verbal. 63.ed. Petrópolis: Vozes, 2007; DIMITRIUS, J.; MAZZARELLA, M. Decifrar pessoas: como entender e prever o comportamento humano. São Paulo: Alegro, 2000.

${ }^{14}$ A fotografia de estúdio, trabalho produzido por um profissional, é habitualmente associada ao século XIX. Boris Kossoy a descreve como um "ato fotográfico teatral”, cujo personagem central é o próprio retratado, ao passo que o fotógrafo desempenha os papéis de diretor da peça, iluminador e contrarregra (KOSSOY, 2001, p.110-111). O ambiente criado nos estúdios era, em regra, composto por móveis rebuscados, entalhados, repletos de detalhes e objetos os mais variados, que podiam ir de um livro, emprestando ao fotografado um ar intelectualizado, a animais, empalhados ou não. Recursos que tinham o objetivo de realçar determinadas características do fotografado, fossem elas reais ou fictícias. Para mais detalhes, consultar: LEMOS, Carlos A. C. Ambientação ilusória. In: MOURA, Carlos E. Marcondes de (Org.). Retratos quase inocentes. São Paulo: Nobel, 1983. p.46-113; TURAZZI, Maria Inês. Poses e trejeitos: a fotografia e as exposições na era do espetáculo (1839-1889). Rio de Janeiro: Funarte; Rocco, 1995; MUAZE, Mariana de Aguiar F. Os guardados da viscondessa: fotografia e memória na coleção Ribeiro de Avellar. Anais do Museu Paulista, São Paulo, v.14, n.2, p.73-105, jul.-dez. 2006; KOUTSOUKOS, Sandra Sofia. M. No estúdio do photographo, o rito da pose (Brasil, segunda metade do século XIX). Revista Agora, Vitória, n.5, p.1-25, 2007. Disponível em: www.ufes.br/ppghis/agora; Acesso em: 27 dez. 2008.

${ }^{15}$ PROST, Antoine; VINCENT, Gérard. História da vida privada: da Primeira Guerra a nossos dias. São Paulo: Companhia das Letras, 1994. p.186.

${ }^{16}$ JACOBSEN, J. Correspondência. Stavanger, Noruega, 16 mai. 1915. Acervo do autor. 
${ }^{17}$ KEEGAN, John. História ilustrada da Primeira Guerra Mundial. 3.ed. Rio de Janeiro: Ediouro, 2004. p.23, 25.

${ }^{18} \mathrm{Da}$ bibliografia disponível sobre o conflito, foram fundamentais para o presente estudo as obras KEEGAN (2004); HOBSBAWM, Eric. Era dos extremos: o breve século XX (19141991). São Paulo: Companhia das Letras, 1995; FERRO, Marc. História da Primeira Guerra Mundial. Lisboa: Edições 70, s.d.; NEVES, Luis F. da Silva. Ciência e tecnologia na Grande Guerra, 1914-1918. In: ASSOCIAÇÃO NACIONAL DE HISTÓRIA. Encontro Estadual de História - ANPUH/Rio de Janeiro, 2004. Disponível em: www.rj.anpuh.org/Anais/2004/ Simposios \%Tematicos; Acesso em: 22 out. 2008. Para muitas das situações descritas, também foram de grande utilidade os relatos de REMARQUE, Erich M. Nada de novo no front. São Paulo: Abril Cultural, 1974, obra de ficção inspirada nas experiências vividas por seu autor como combatente nas trincheiras alemãs.

${ }^{19}$ Optou-se por omitir os sobrenomes dos fotografados. Prenomes e datas mencionados correspondem às anotações presentes no álbum e/ou nas fotografias.

${ }^{20}$ MACHADO JÚNIOR, Cláudio de Sá. Escrevendo a História com imagens fotográficas: historiografia das principais tendências no Brasil. In: ASSOCIAÇÃO NACIONAL DE HISTÓRIA. IX Encontro Estadual de História - ANPUH/Rio Grande do Sul, 2008. Disponível em: www.eeh2008.anpuh-rs.org.br; Acesso em: 13 dez. 2008.

${ }^{21}$ Miriam Moreira Leite observa que, "como a câmera assume o lugar do observador ou leitor da fotografia, amplia o sentido do fotografado quando olha de baixo para cima e reduz sua importância quando o olha de cima para baixo" (LEITE, 2001, p.137).

${ }^{22}$ MAUAD, Ana Maria. Genevieve Naylor, fotógrafa: impressões de viagem (Brasil, 19411942). Revista Brasileira de História, São Paulo, v.25, n.49, p.43-75, 2005. p.65-66.

${ }^{23}$ Outras anotações que acompanham os retratos dão força a essa suposição. É o caso de fotografias de Frieda e de Anton com a observação "mamãe" e "papai”. Há, contudo, observações de outra autoria, por exemplo, identificando retratos de Maria Christine, em idade adulta, como "Tia Mia”.

${ }^{24}$ Ver nota 3.

Artigo recebido em fevereiro de 2009. Aprovado em outubro de 2009. 